\title{
Synthesis and structure refinement of layered double hydroxides of Co, Mg and Ni with Ga
}

\author{
G V MANOHARA and P VISHNU KAMATH* \\ Department of Chemistry, Central College, Bangalore University, Bangalore 560 001, India
}

MS received 23 May 2009

\begin{abstract}
Homogeneous precipitation by urea hydrolysis results in the formation of highly ordered layered double hydroxides of divalent metal ions $(\mathrm{Co}, \mathrm{Mg}, \mathrm{Ni})$ and $\mathrm{Ga}$. Structure refinement shows that these carbonate containing layered hydroxides crystallize with rhombohedral symmetry (space group $R-3 m$ ) in the structure of the $3 R_{1}$ polytype. An analysis of the structure shows that, coulombic attraction between the layer and interlayer remains invariant in different layered hydroxides, whereas the strength of hydrogen bonding varies. The Ni-Ga LDH has the weakest hydrogen bonding and $\mathrm{Co}-\mathrm{Ga}$, the strongest, as reflected by the layer-interlayer oxygen-oxygen distances. The poor polarity of the $\mathrm{OH}$ bond in the $\mathrm{Ni}-\mathrm{Ga}$ hydroxide points to the greater covalency of the $\left(\mathrm{M}^{2+} / \mathrm{M}^{3+}\right)$-oxygen bond in this compound as opposed to the Co-Ga hydroxide. These observations are supported by IR spectra.
\end{abstract}

Keywords. Layered double hydroxide; Rietveld refinement; urea hydrolysis.

\section{Introduction}

The synthesis, structure and properties of layered double hydroxides (LDHs) have been widely studied in recent years because of their potential applications in catalysis (Cavani et al 1991), ion exchange (Khan and O'Hare 2002), environmental amelioration (Fetter et al 1997) and other areas (Grardin et al 2005; Gursky et al 2006; Gago et al 2008). LDHs consist of positively charged metal hydroxide layers having the composition $\left[\mathrm{M}^{\mathrm{II}}{ }_{1-x} \mathrm{M}^{\prime}{ }_{x} \mathrm{II}\right.$ $\left.(\mathrm{OH})_{2}\right]^{x+}\left(\mathrm{M}^{\mathrm{II}}=\mathrm{Mg}, \mathrm{Ca}, \mathrm{Co}, \mathrm{Ni}, \mathrm{Cu}, \mathrm{Zn} ; \mathrm{M}^{\prime I I I}=\mathrm{Al}, \mathrm{Cr}\right.$, $\mathrm{Fe} ; 0.2 \leq x \leq 0.33)$. The positive charge on the layers is balanced by anions present in the interlayer. This results in a general formula, $\left[\mathrm{M}^{\mathrm{II}}{ }_{1-x} \mathrm{M}^{\prime \mathrm{III}}{ }_{x}(\mathrm{OH})_{2}\right]\left(\mathrm{A}^{n-}\right)_{x / n} \cdot m \mathrm{H}_{2} \mathrm{O}$ $(m=0.33-0 \cdot 50)$. The most commonly found anion in naturally occurring LDHs is $\mathrm{CO}_{3}^{2-}$ (Taylor 1973).

To arrive at appropriate structure-property correlations, it is necessary to have a comprehensive understanding of the crystal chemistry of LDHs. This is rendered difficult for many reasons: (i) In common with other layered materials, LDHs exhibit extensive polytypism (Bookin and Drits 1993). Although the structures of different polytypes differ significantly from one another, these differences often manifest themselves in only minor changes in the powder X-ray diffraction (PXRD) patterns, (ii) the LDHs exhibit considerable compositional variability and cation disorder and (iii) on account of the anisotropy in bonding, the LDHs crystallize with exten-

\footnotetext{
*Author for correspondence (vishnukamath8@hotmail.com)
}

sive structural disorder. Chief among these are stacking faults, which are incorporated during crystal growth and once incorporated cannot be eliminated even by prolonged hydrothermal treatment (Bellotto et al 1996). Structural disorder manifests itself by excessive and nonuniform broadening of different families of reflections in the PXRD pattern of the material (Thomas et al 2004).

On account of these factors, the synthesis of ordered LDHs and refinement of their structures poses a considerable challenge. Further, the widening range of applications has sparked the synthesis of LDHs comprising a very wide variety of trivalent cations such as Ga and In (Aramendia et al 1997, 1999) combined with $\mathrm{Co}, \mathrm{Mg}, \mathrm{Ni}$ and other divalent cations. These cations differ significantly from one another in their ionic radii, hydrolysis behaviour, solubility and coordination, rendering the crystal chemistry of the LDHs even more complex.

There have been many attempts to synthesize ordered LDHs. Most of these have been modifications of the coprecipitation technique (Reichle 1986). Grosso et al (1992) examined all the parameters that affect the outcome of a precipitation reaction, in their study of the synthesis of the $\mathrm{Cu}-\mathrm{Cr} \mathrm{LDH}$. Zhao et al (2002) used a highspeed stirring procedure in order to separate the nucleation step from the growth step, in an attempt to prepare an ordered LDH. But these attempts did not lead to the synthesis of ordered materials.

In contrast, homogeneous precipitation from solution (HPFS) by hydrolysis of urea (Costantino et al 1998; Adachi-Pagano et al 2003) yielded ordered LDHs, facilitating structure refinement of $\left[\mathrm{M}-\mathrm{Al}-\mathrm{CO}_{3}\right](\mathrm{M}=\mathrm{Mg}, \mathrm{Co}$, 
Table 1. Synthesis conditions employed for the homogeneous precipitation of LDHs.

\begin{tabular}{lcccccc}
\hline $\mathrm{LDH}$ & Metal ion conc. $[\mathrm{M}]$ & {$\left[\mathrm{M}^{3+}\right] /\left[\mathrm{M}^{3+}+\mathrm{M}^{\prime 2+}\right]$} & {$[\mathrm{Urea}] /[\mathrm{M}]$} & $T\left({ }^{\circ} \mathrm{C}\right)$ & $t(\mathrm{~h})$ & Final $\mathrm{pH}$ \\
\hline $\mathrm{Mg}-\mathrm{Ga}-\mathrm{CO}_{3}$ & $0 \cdot 25$ & 3 & 5 & 90 & 24 & $7 \cdot 81$ \\
$\mathrm{Ni}-\mathrm{Ga}-\mathrm{CO}_{3}$ & $0 \cdot 5$ & 2 & $3 \cdot 3$ & 140 & 24 & $8 \cdot 64$ \\
$\mathrm{Co}-\mathrm{Ga}-\mathrm{CO}_{3}$ & $0 \cdot 5$ & 2 & $3 \cdot 3$ & 110 & 24 & $7 \cdot 75$ \\
\hline
\end{tabular}

Ni) LDHs (Radha et al 2007). In this paper, we use the urea hydrolysis technique to synthesize a cohort of recently reported $\mathrm{LDHs}\left[\mathrm{M}-\mathrm{Ga}-\mathrm{CO}_{3}\right]$, where $\mathrm{M}=\mathrm{Co}$, $\mathrm{Mg}, \mathrm{Ni}$ and refine their structure by the Rietveld method.

\section{Experimental}

$\mathrm{Mg}\left(\mathrm{NO}_{3}\right)_{2} \cdot 6 \mathrm{H}_{2} \mathrm{O}, \mathrm{Ni}\left(\mathrm{NO}_{3}\right)_{2} \cdot 6 \mathrm{H}_{2} \mathrm{O}, \mathrm{Co}\left(\mathrm{NO}_{3}\right)_{2} \cdot 6 \mathrm{H}_{2} \mathrm{O}$ (Merck, India) and $\mathrm{Ga}\left(\mathrm{NO}_{3}\right)_{3} \cdot \mathrm{xH}_{2} \mathrm{O}$ (Sigma Aldrich Chemical Co., USA) were procured from commercial sources and used as starting materials without further purification. For the preparation of $\mathrm{Ni}-\mathrm{Ga}$ and $\mathrm{Co}-\mathrm{Ga} \mathrm{LDHs}, 40 \mathrm{~mL}$ of a mixed metal nitrate solution (total concentration, $0.5 \mathrm{M}$ ) containing the required mole ratio $\left(\left[\mathrm{M}^{\mathrm{II}}\right] /\left[\mathrm{M}^{\prime \text { III }}\right]=2\right)$ of the cations was taken. In the case of $\mathrm{Mg}-\mathrm{Ga} \mathrm{LDH}$, a lower salt concentration $(0.25 \mathrm{M})$ of the mixed metal nitrate solution was used. Solid urea was added to the metal nitrate solution ([urea]/[total metal] $=3 \cdot 3-5)$. Several batches of the clear solutions were hydrothermally treated in Teflon lined stainless steel autoclaves at different temperatures ranging from $90-140^{\circ} \mathrm{C}$ for $24 \mathrm{~h}$. The resulting solids were washed with copious amount of water (specific resistance, $15 \mathrm{M} \Omega \mathrm{cm}$, Millipore Elix 3 water purification system) and dried at $60^{\circ} \mathrm{C}$ for $24 \mathrm{~h}$. Detailed experimental conditions used for the synthesis of different LDHs are given in table 1. Control samples were obtained by co-precipitation using the Reichle (1986) procedure. The mixed metal nitrate solutions taken as above were added (dropping rate, $3 \mathrm{~mL} \mathrm{~min}^{-1}$ ) to a $2 \mathrm{M}$ solution of $\mathrm{NaOH}$ containing three times the stoichiometric requirement of $\mathrm{Na}_{2} \mathrm{CO}_{3}$.

All samples were characterized by powder X-ray diffraction (PXRD) using Bruker aXS Model D8 Advance diffractometer ( $\mathrm{CuK} \alpha$ radiation, $\lambda=1.541 \AA)$. Data were collected over a $2 \theta$ range of $5-100^{\circ}$ (step size of $0.02^{\circ} 2 \theta$, counting time, $10 \mathrm{~s} / \mathrm{step}$ ). Data of Co-containing LDHs were acquired using a bent crystal secondary monochromator to eliminate fluorescent emission $\left(5-100^{\circ} 2 \theta\right.$, step size $0.017^{\circ} 2 \theta$, total counting time, $14 \mathrm{~h}$ ). IR spectra (SHIMADZU FTIR-8400S, $\mathrm{KBr}$ pellet, $4 \mathrm{~cm}^{-1}$ resolution) were obtained to verify the presence of intercalated anions. Thermal behaviour of all the LDHs was studied using Mettler Toledo TGA/SDTA Model $851^{\mathrm{e}}$ driven by $\mathrm{star}^{\mathrm{e}}$ software (heating rate $5^{\circ} \mathrm{C} \mathrm{min}^{-1}$, flowing $\mathrm{N}_{2}$ ). The morphology of the samples was studied using a JEOL JSM 6490 LV scanning electron microscope, operated at
$15 \mathrm{kV}$ accelerating voltage. The powder samples were scattered over conducting graphite tape and sputter coated with Pt.

The Rietveld technique was employed for structure refinement (FULLPROF; Rodriguez-Carvajal 2005). For Ni-Ga LDH, Pearson VII line shape function with six variables $(U, V, W, X, Y$ and $M$ ) was used to fit the experimental profile. In case of $\mathrm{Co}-\mathrm{Ga}$ and $\mathrm{Mg}-\mathrm{Ga}$ LDHs, the modified psuedo-Voigt line shape function with five variables ( $U, V, W, X$ and $\eta)$ was used. MarchDollase correction was employed to model the preferred orientation of crystallites observed in $\mathrm{M}-\mathrm{Ga}(\mathrm{M}=\mathrm{Ni}, \mathrm{Co})$ LDHs. The background was corrected using a 6 coefficient polynomial for $\mathrm{Ni}-\mathrm{Ga}$ and $\mathrm{Co}-\mathrm{Ga} \mathrm{LDHs}$; in case of the $\mathrm{Mg}-\mathrm{Ga} \mathrm{LDH}$, a 12 coefficient polynomial was used. The structure of $\mathrm{Mg}-\mathrm{Al}-\mathrm{CO}_{3}$ (CC 86655, space group $R-3 m, a=3.0453 \AA, c=22.701 \AA$ ) was used as the model for refinement.

\section{Results and discussion}

Crystal growth takes place by layer-by-layer accretion of atoms. In the specific case of layered hydroxides, successive addition of metal hydroxide slabs leads to crystal growth from a supersaturated solution. A typical metal hydroxide slab may be described as $A b C$ (or more simply $A C$ ), where symbols $A, B, C$ represent positions of the hydroxyl ions in a close packed array and $a, b, c$ represent the octahedral interstitial sites occupied by the cation. Crystal growth by the accretion of identical layers $A C A C A C \ldots$ leads to a hexagonal polytype of one-layer periodicity (1H) (Bookin and Drits 1993). All binary hydroxides, $\mathrm{M}(\mathrm{OH})_{2}(\mathrm{M}=\mathrm{Mg}, \mathrm{Ca}, \mathrm{Mn}, \mathrm{Fe}, \mathrm{Co}, \mathrm{Ni})$, crystallize in this structure. However, in principle, other layers such as $A B, B C, C A$ and others, could also get incorporated during crystal growth, leading to a wide range of polytypes. These different slabs are related to one another by translation or reflection.

Among LDHs, the stacking sequence of successive metal hydroxide slabs is mediated by anions in the interlayer. Carbonate ions mediate growth patterns that generate trigonal prismatic interlayer sites (Taylor 1973). This preference is on account of the enhanced hydrogen bonding that accrues between the carbonate ions and the hydroxyl ions of the metal hydroxide slabs defining the trigonal prismatic site. 
Among many others, two distinct polytypes that generate trigonal prismatic sites have been identified in mineralogical samples (Allmann 1969; Taylor 1973):

$$
\begin{aligned}
& A C C A A C C A A C C A \ldots 2 H_{1}, \\
& A C C B B A A C C B B A \ldots 3 R_{1} .
\end{aligned}
$$

It is clear that these two polytypes have similar short range interactions and therefore can be expected to have very similar energies of formation. Consequently, laboratory prepared samples are generally a random intergrowth of these two polytypes. This kind of structural disorder manifests in the non-uniform broadening of the $0 \mathrm{kl} / \mathrm{h} 0 \mathrm{l}$ reflections in the PXRD patterns of the LDHs (Drits and Bookin 2001). In figure 1 are shown representative PXRD patterns of the $\left[\mathrm{M}-\mathrm{Ga}-\mathrm{CO}_{3}^{2-}\right](\mathrm{M}=\mathrm{Mg}, \mathrm{Ni}) \mathrm{LDHs}$ prepared by co-precipitation. The PXRD pattern of the Ni-based LDH exhibits only four broad features. The two low angle reflections appearing below $25^{\circ} 2 \theta$ are due to the basal reflections $00 l(l=1,2)$. Two 'saw-tooth' shaped reflections appear at high angles. The asymmetric broadening of the peaks on the high angle side, also called Warren-broadening (Hines et al 1997) is on account of turbostratic disorder arising due to the loss of registry between successive layers. The random rotation/translation of the metal hydroxide layers relative to one another destroys 3-dimensional periodicity, although each layer is periodic in two-dimensions. The observed peaks are assigned to the 2-dimensional reflections, 10 and 11. These PXRD patterns are similar to those reported by other authors (Defontaine et al 2000). The PXRD pattern of the $\mathrm{Mg}-\mathrm{Ga} \mathrm{LDH}$ exhibits peaks due to the $01 l(l=2,5,8)$ reflections but the peaks are nonuniformly broadened indicating the incorporation of stacking faults. It is, in general, evident that the crystallinity of the samples is inadequate to carry out structure refinement.

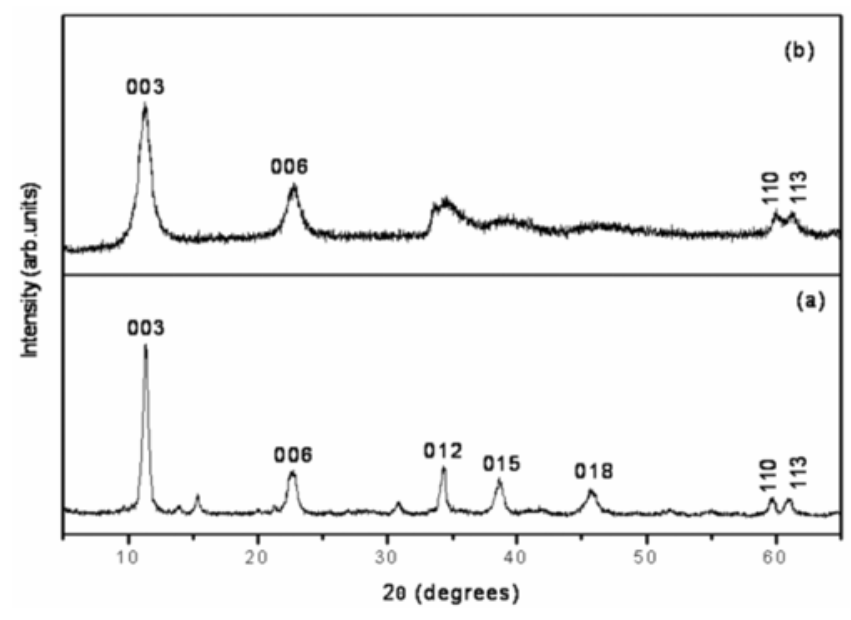

Figure 1. PXRD pattern of the co-precipitated (a) $\mathrm{Mg}-\mathrm{Ga}-$ $\mathrm{CO}_{3}$ and (b) $\mathrm{Ni}-\mathrm{Ga}-\mathrm{CO}_{3}$ LDHs.
One of the reasons for the formation of highly disordered LDHs is the very rapid rate of crystallization during a co-precipitation reaction. Homogeneous precipitation helps to slow down the rate of precipitation.

The PXRD patterns of the $\left[\mathrm{M}-\mathrm{Ga}-\mathrm{CO}_{3}\right]$ LDHs $(\mathrm{M}=\mathrm{Ni}, \mathrm{Co}, \mathrm{Mg})$ obtained by HPFS by urea hydrolysis comprise sharp peaks with uniform width reflecting the high degree of structural order. Rietveld refinement of the structures of all the three LDHs (figures 2-4) was carried out by excluding the impurity reflections $/ \mathrm{K} \beta$ features (see supporting information SI 1-2 for the raw data of $\mathrm{Co}-\mathrm{Ga}$ and $\mathrm{Mg}-\mathrm{Ga} \mathrm{LDHs}$, respectively) and results are given in tables 2 and 3 . All the structures were refined within the space group $R-3 m$. This structure model corresponds to the $3 R_{1}$ polytype. In this structure (figure 5a) there are several sites in the interlayer available for occupation by

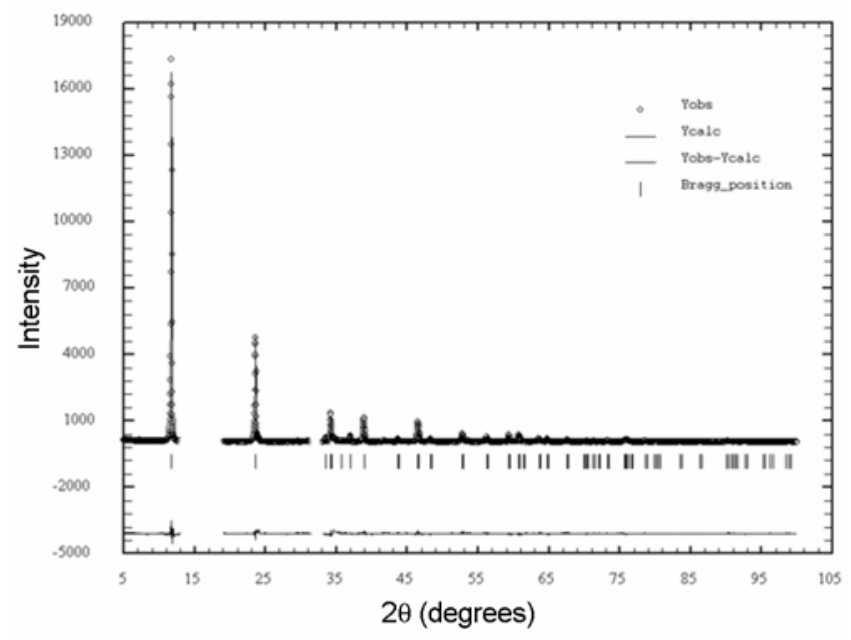

Figure 2. Rietveld fit of the PXRD pattern of $\mathrm{Co}-\mathrm{Ga}-\mathrm{CO}_{3}$ LDH prepared by HPFS method. The excluded region contains features due to impurities.

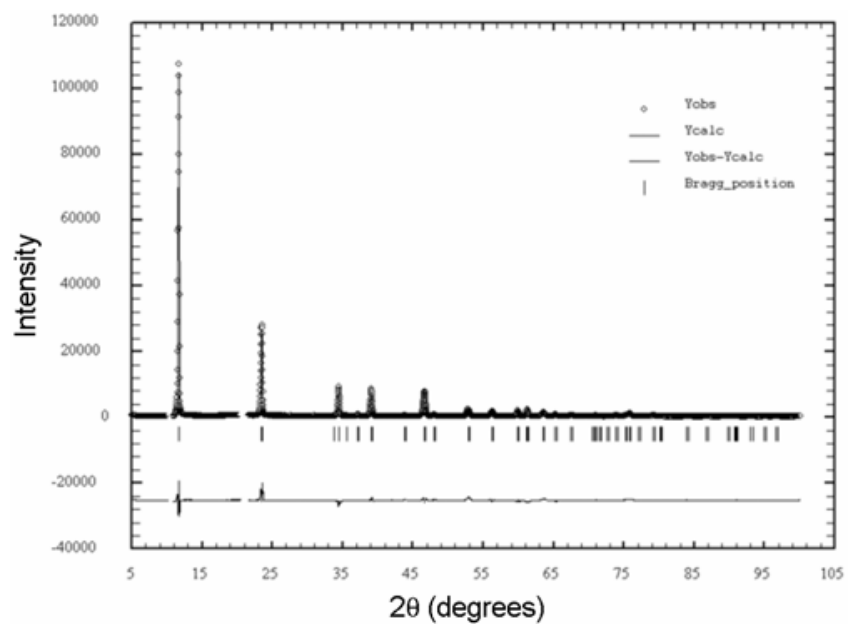

Figure 3. Rietveld fit of the PXRD pattern of $\mathrm{Mg}-\mathrm{Ga}-\mathrm{CO}_{3}$ LDH prepared by HPFS method. The excluded region contains features due to the $\mathrm{K} \beta$ radiation. 
Table 2. Results of Rietveld refinement of the $\mathrm{M}-\mathrm{Ga}(\mathrm{M}=\mathrm{Ni}, \mathrm{Co}, \mathrm{Mg}) \mathrm{LDHs}$.

\begin{tabular}{|c|c|c|c|}
\hline & $\mathrm{Ni}_{4} \mathrm{Ga}_{2}(\mathrm{OH})_{12} \mathrm{CO}_{3} \cdot 3 \mathrm{H}_{2} \mathrm{O}$ & $\mathrm{Co}_{4} \mathrm{Ga}_{2}(\mathrm{OH})_{12} \mathrm{CO}_{3} \cdot 3 \mathrm{H}_{2} \mathrm{O}$ & $\mathrm{Mg}_{6} \mathrm{Ga}_{2}(\mathrm{OH})_{16} \mathrm{CO}_{3} \cdot 4 \mathrm{H}_{2} \mathrm{O}$ \\
\hline Space group & $R-3 m$ & $R-3 m$ & $R-3 m$ \\
\hline $\begin{array}{l}\text { Cell parameter } \\
\quad a(\AA) \\
c(\AA)\end{array}$ & $\begin{array}{r}3 \cdot 0714(3) \\
22 \cdot 8266(2)\end{array}$ & $\begin{array}{r}3 \cdot 1103(2) \\
22 \cdot 6157(3)\end{array}$ & $\begin{array}{r}3 \cdot 0867(2) \\
22 \cdot 7284(2)\end{array}$ \\
\hline $\begin{array}{l}\text { Shape parameters } \\
U \\
V \\
W \\
X \\
Y \\
M \\
\eta\end{array}$ & $\begin{array}{c}0 \cdot 7340(2) \\
-0 \cdot 0100(8) \\
0 \cdot 0807(1) \\
0 \cdot 1612(7) \\
-0 \cdot 0146(3) \\
1.0366(3) \\
-\end{array}$ & $\begin{array}{c}0.0409(2) \\
-0.0111(2) \\
0.0183(2) \\
0.0103(2) \\
- \\
- \\
0.4311(3)\end{array}$ & $\begin{array}{c}0 \cdot 3417(6) \\
-0 \cdot 0010(9) \\
0 \cdot 0194(4) \\
0 \cdot 0010(3) \\
- \\
- \\
0 \cdot 3084(8)\end{array}$ \\
\hline $\begin{array}{l}\text { Preferred orientation } \\
\quad G 1 \\
\quad G 2\end{array}$ & $\begin{array}{l}0.4930 \\
0.9285\end{array}$ & $\begin{array}{l}0.5489 \\
0.7364\end{array}$ & $\begin{array}{l}- \\
-\end{array}$ \\
\hline $\begin{array}{l}\text { Goodness-of-fit } \\
R_{\mathrm{wp}} \\
R_{\text {Bragg }} \\
R_{\mathrm{F}} \\
R_{\mathrm{p}} \\
\chi^{2}\end{array}$ & $\begin{array}{r}14 \cdot 9 \\
5 \cdot 17 \\
7 \cdot 77 \\
18 \cdot 70 \\
8 \cdot 38\end{array}$ & $\begin{array}{c}21 \cdot 6 \\
4 \cdot 94 \\
7 \cdot 33 \\
18 \cdot 4 \\
2 \cdot 75\end{array}$ & $\begin{array}{c}16 \cdot 9 \\
7 \cdot 25 \\
8 \cdot 8 \\
14 \cdot 7 \\
11 \cdot 1\end{array}$ \\
\hline $\begin{array}{l}\text { Distances }(\AA) \\
(\mathrm{M}, \mathrm{Ga})-\mathrm{O}_{1} \\
\mathrm{O}_{1}-\mathrm{O}_{1} \text { (shared) } \\
\mathrm{O}_{1}-\mathrm{O}_{1} \text { (in-plane) } \\
(\mathrm{M}, \mathrm{Ga})-\mathrm{O}_{2} \\
\mathrm{O}_{1}-\mathrm{O}_{2} \\
\mathrm{C}-\mathrm{O}_{2}\end{array}$ & $\begin{array}{r}1.9914(2) \\
2 \cdot 5358(3) \\
3 \cdot 0714(4) \\
3 \cdot 9832(2) \\
3 \cdot 8767(12) \\
1 \cdot 1799(2)\end{array}$ & $\begin{array}{l}2 \cdot 0647(4) \\
2 \cdot 7162(3) \\
3 \cdot 1103(2) \\
3 \cdot 9494(2) \\
2 \cdot 8208(9) \\
1 \cdot 2303(2)\end{array}$ & $\begin{array}{r}2.0466(2) \\
2 \cdot 6883(19) \\
3.0867(6) \\
3.9745(5) \\
3.6980(8) \\
1 \cdot 1823(10)\end{array}$ \\
\hline $\begin{array}{l}\text { Angles }\left({ }^{\circ}\right) \\
\qquad \mathrm{O}_{1}-(\mathrm{M}, \mathrm{Ga})-\mathrm{O}_{1} \\
\mathrm{O}_{1}-(\mathrm{M}, \mathrm{Ga})-\mathrm{O}_{1} \\
\mathrm{O}_{2}-\mathrm{C}-\mathrm{O}_{2}\end{array}$ & $\begin{array}{l}114.08(3) \\
65.91(16) \\
120 \cdot 01(3)\end{array}$ & $\begin{array}{r}97 \cdot 73(4) \\
82 \cdot 26(18) \\
120 \cdot 00(4)\end{array}$ & $\begin{array}{r}112.91(2) \\
67.09(2) \\
120.00(3)\end{array}$ \\
\hline
\end{tabular}

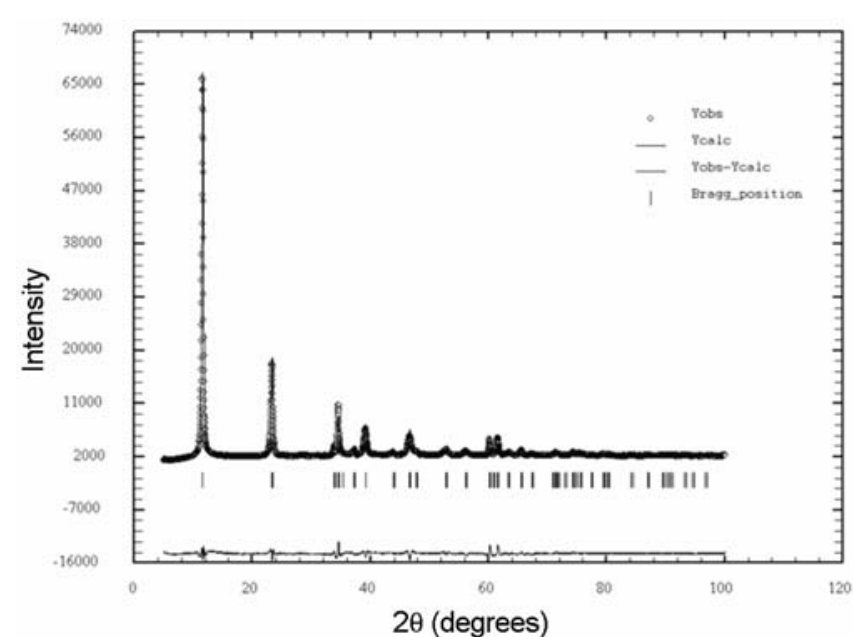

Figure 4. Rietveld fit of the PXRD pattern of $\mathrm{Ni}-\mathrm{Ga}-\mathrm{CO}_{3}$ LDH prepared by HPFS method.

the intercalated atoms. The $6 c$ site is the most proximal to the metal ion and lies directly below it. The site most proximal to the oxygen of the hydroxyl ion $\left(\mathrm{O}_{1}\right)$ is the $3 b$.
The layer-interlayer bonding in LDHs arises out of two interactions: (i) the coulombic attraction between the positively charged metal hydroxide layer and the negatively charged interlayer and (ii) hydrogen bonding between the metal hydroxide slabs and the intercalated oxygen $\left(\mathrm{O}_{2}\right)$ atoms.

The $6 c$ is favoured by purely coulombic interactions, whereas the $3 b$ is favoured by purely $\mathrm{H}$-bonding interactions. In this structure, the $\mathrm{O}_{2}$ atom which is the seat of the negative charge occupies the $18 \mathrm{~h}$ site, the corresponding atom positions lie at the vertices of a hexagon, around the $3 b$ site. The $18 h$ site offers the best bonding arising due to the combination of both coulombic and H-bonding interactions.

From the refinement, the distance between the metal $\left(\mathrm{M}^{\mathrm{II}} / \mathrm{M}^{\prime \mathrm{III}}\right)$ and the oxygen of the hydroxyl ion $\left(\mathrm{O}_{1}\right)$ was found to vary in the order $\mathrm{Co}-\mathrm{Ga}(2.07 \AA)>\mathrm{Mg}-\mathrm{Ga}$ $(2.05 \AA)>\mathrm{Ni}-\mathrm{Ga}(1.99 \AA)$. This progressive decrease in the metal-hydroxyl bond length correlates with the average cationic radius of the three LDHs, which also varies in the same order: $\mathrm{Co}-\mathrm{Ga}(0.8533 \AA)>\mathrm{Mg}-\mathrm{Ga}$ 
Table 3. Position parameters obtained from the Rietveld refinement of the $\mathrm{M}-\mathrm{Ga}(\mathrm{M}=\mathrm{Ni}, \mathrm{Co}, \mathrm{Mg})$ LDHs.

\begin{tabular}{|c|c|c|c|c|c|}
\hline & Atom & Site & $x$ & $y$ & $z$ \\
\hline $\mathrm{Ni}_{4} \mathrm{Ga}_{2}(\mathrm{OH})_{12} \mathrm{CO}_{3} \cdot 3 \mathrm{H}_{2} \mathrm{O}$ & $\begin{array}{l}\mathrm{Ni} \\
\mathrm{Ga} \\
\mathrm{O} 1 \\
\mathrm{C} \\
\mathrm{O} 2 \\
\mathrm{H} 1 \\
\mathrm{H} 2\end{array}$ & $\begin{array}{l}3(\mathrm{a}) \\
3(\mathrm{a}) \\
6(\mathrm{c}) \\
6(\mathrm{c}) \\
18(\mathrm{~h}) \\
6(\mathrm{c}) \\
6(\mathrm{c})\end{array}$ & $\begin{array}{l}0 \cdot 000 \\
0 \cdot 000 \\
0 \cdot 000 \\
0 \cdot 3333 \\
0 \cdot 1114(2) \\
0 \cdot 000 \\
0 \cdot 3333\end{array}$ & $\begin{array}{l}0 \cdot 000 \\
0 \cdot 000 \\
0 \cdot 000 \\
0 \cdot 6667 \\
0 \cdot 8885(2) \\
0 \cdot 000 \\
0 \cdot 6667\end{array}$ & $\begin{array}{l}0 \cdot 000 \\
0 \cdot 000 \\
0 \cdot 3730(5) \\
0 \cdot 5000 \\
0 \cdot 5000 \\
0 \cdot 4220(17) \\
0 \cdot 5000\end{array}$ \\
\hline $\mathrm{Co}_{4} \mathrm{Ga}_{2}(\mathrm{OH})_{12} \mathrm{CO}_{3} \cdot 3 \mathrm{H}_{2} \mathrm{O}$ & $\begin{array}{l}\mathrm{Co} \\
\mathrm{Ga} \\
\mathrm{O} \\
\mathrm{C} \\
\mathrm{O} 2 \\
\mathrm{H} 1 \\
\mathrm{H} 2\end{array}$ & $\begin{array}{l}3(\mathrm{a}) \\
3(\mathrm{a}) \\
6(\mathrm{c}) \\
6(\mathrm{c}) \\
18(\mathrm{~h}) \\
6(\mathrm{c}) \\
6(\mathrm{c})\end{array}$ & $\begin{array}{l}0 \cdot 000 \\
0 \cdot 000 \\
0 \cdot 000 \\
0 \cdot 3333 \\
0 \cdot 1099(3) \\
0 \cdot 000 \\
0 \cdot 3333\end{array}$ & $\begin{array}{l}0 \cdot 000 \\
0 \cdot 000 \\
0 \cdot 000 \\
0 \cdot 6667 \\
0 \cdot 8900(3) \\
0 \cdot 000 \\
0 \cdot 6667\end{array}$ & $\begin{array}{l}0 \cdot 000 \\
0 \cdot 000 \\
0 \cdot 3785(2) \\
0 \cdot 5000 \\
0 \cdot 5000 \\
0 \cdot 4220(17) \\
0 \cdot 5000\end{array}$ \\
\hline $\mathrm{Mg}_{6} \mathrm{Ga}_{2}(\mathrm{OH})_{16} \mathrm{CO}_{3} \cdot 4 \mathrm{H}_{2} \mathrm{O}$ & $\begin{array}{l}\mathrm{Mg} \\
\mathrm{Ga} \\
\mathrm{O} 1 \\
\mathrm{C} \\
\mathrm{O} 2 \\
\mathrm{H} 1 \\
\mathrm{H} 2\end{array}$ & $\begin{array}{l}3(a) \\
3(a) \\
6(c) \\
6(c) \\
18(h) \\
6(c) \\
6(c)\end{array}$ & $\begin{array}{l}0 \cdot 000 \\
0 \cdot 000 \\
0 \cdot 000 \\
0 \cdot 3333 \\
0 \cdot 1121(2) \\
0 \cdot 000 \\
0 \cdot 3333\end{array}$ & $\begin{array}{l}0 \cdot 000 \\
0 \cdot 000 \\
0 \cdot 000 \\
0 \cdot 6667 \\
0 \cdot 8878(2) \\
0 \cdot 000 \\
0 \cdot 6667\end{array}$ & $\begin{array}{l}0 \cdot 000 \\
0 \cdot 000 \\
0 \cdot 3776(10) \\
0 \cdot 5000 \\
0 \cdot 5000 \\
0 \cdot 4220(17) \\
0 \cdot 5000\end{array}$ \\
\hline
\end{tabular}
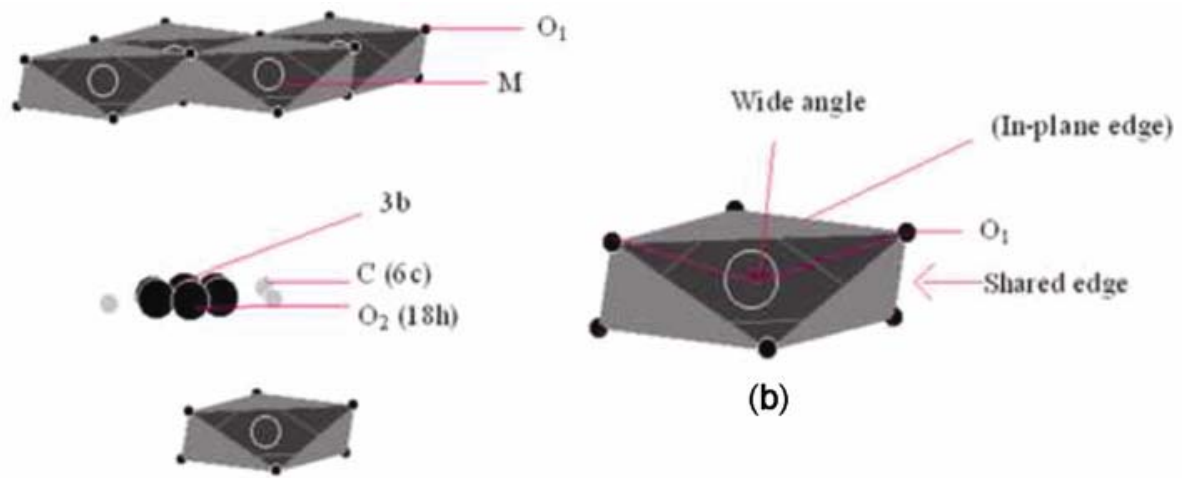

(b)

(a)

Figure 5. (a) Schematic structural representation of the interlayer indicating the various sites and (b) $\left[\mathrm{MO}_{6}\right]$ coordination polygon with three-fold symmetry.

$(0.8425 \AA)>\mathrm{Ni}-\mathrm{Ga} \quad(0.8166 \AA) \quad\left[r\left(\mathrm{Co}^{2+}\right)=0.885 \AA\right.$ $r\left(\mathrm{Mg}^{2+}\right)=0.86 \AA ; \quad r\left(\mathrm{Ga}^{2+}\right)=0.76 \AA ; \quad r\left(\mathrm{Ni}^{2+}\right)=0.83 \AA ;$ $\mathrm{Co}^{2+} / \mathrm{Ga}^{3+}=2 ; \mathrm{Ni}^{2+} / \mathrm{Ga}^{3+}=2 ; \mathrm{Mg}^{2+} / \mathrm{Ga}^{3+}=3$ ] (Shannon 1976). A shorter metal-hydroxyl bond length is indicative of greater covalency, indicating the $\mathrm{Ni}-\mathrm{Ga} \mathrm{LDH}$ is in general more covalent than the other LDHs.

The $\mathrm{O}_{1}-\left(\mathrm{M}^{\mathrm{II}} / \mathrm{M}^{\prime \mathrm{III}}\right)-\mathrm{O}_{1}$ angles are substantially different from $90^{\circ}$, showing the $\left[\mathrm{MO}_{6}\right]$ octahedra are distorted, even as the 3 -fold axis is conserved. This yields two $\mathrm{O}_{1}-\mathrm{O}_{1}$ distances: one measured perpendicular to the $c$-crystallographic axis (in plane) and the other parallel to the $c$-axis (figure 5b). The latter is in fact the thickness of the metal hydroxide slab and corresponds to the shared octahedral edge. The in-plane $\mathrm{O}_{1}-\mathrm{O}_{1}$ distances are larger and are defined by the wide $\mathrm{O}_{1}-\left(\mathrm{M}^{\mathrm{II}} / \mathrm{M}^{\prime}{ }^{\mathrm{III}}\right)-\mathrm{O}_{1}$ angle. The distortion is the most in the Ni-Ga $\mathrm{LDH}$, where the $\mathrm{O}_{1}-\mathrm{M}-\mathrm{O}_{1}$ angles are $114^{\circ}$ and $66^{\circ}$. This yields an in-plane $\mathrm{O}_{1}-\mathrm{O}_{1}$ distance of $3.07 \AA$, whereas shared octahedral edge is only $2.536 \AA$. The distortion in the case of the $\mathrm{Co}-\mathrm{Ga} \mathrm{LDH}$ is much less. The $\mathrm{Mg}-\mathrm{Ga} \mathrm{LDH}$ represents an intermediate case although closer to the $\mathrm{Ni}-\mathrm{Ga}$ $\mathrm{LDH}$. The length of the shared octahedral edge varies as Co-Ga $(2.72 \AA)>\mathrm{Mg}-\mathrm{Ga}(2.69 \AA)>\mathrm{Ni}-\mathrm{Ga}(2.54 \AA)$.

The $\mathrm{O}_{1}-\mathrm{O}_{2}$ distance represents effectively the hydrogen bonding distance. There is a very large variation in the three LDHs: Co-Ga $(2 \cdot 82 \AA)<\mathrm{Mg}-\mathrm{Ga}(3 \cdot 70 \AA)<\mathrm{Ni}-\mathrm{Ga}$ $(3.88 \AA)$. The variation across the series is $\sim 25 \%$ showing that hydrogen bonding between the layer and inter- 
layer is strongest in the $\mathrm{Co}-\mathrm{Ga} \mathrm{LDH}$ and weakest in the $\mathrm{Ni}-\mathrm{Ga} \mathrm{LDH}$. Experimental evidence for this can be found in IR spectra (figure 6) where the FWHM of the $\mathrm{CO}_{3}^{2-}$ vibration is much lower in the $\mathrm{Ni}-\mathrm{Ga} \mathrm{LDH}\left(52 \mathrm{~cm}^{-1}\right)$ compared with the other LDHs (Mg-Ga LDH: $140 \mathrm{~cm}^{-1}$; Co-Ga LDH: $78 \mathrm{~cm}^{-1}$ ).

A large $\mathrm{O}_{1}-\mathrm{O}_{2}$ distance surprisingly does not reflect in the $\left(\mathrm{M}^{\mathrm{II}} / \mathrm{M}^{\prime \mathrm{III}}\right)-\mathrm{O}_{2}$ distance. The latter remains almost constant in all the LDHs (3.97 $\pm 0.01 \AA$ ) (see table 2). The $\mathrm{O}_{1}-\mathrm{O}_{2}$ distance is tuned by the variation in the $\mathrm{O}_{1}-\left(\mathrm{M}^{\mathrm{II}} / \mathrm{M}^{\prime \mathrm{III}}\right)-\mathrm{O}_{1}$ angle. It is seen that the layer thickness correlates negatively with the $\mathrm{O}_{1}-\mathrm{O}_{2}$ distance. These observations give an insight into the nature of bonding in the LDHs.

Given that the positive charge of the layer is localized on the metal cation, the $\left(\mathrm{M}^{\mathrm{II}} / \mathrm{M}^{\prime \mathrm{III}}\right)-\mathrm{O}_{2}$ distance is determined by the coulombic forces between the layer and the interlayer. The fact that this distance varies very little in the three LDHs shows that the coulombic interaction is similar and independent of the $\mathrm{M}^{2+}$ ion. The only variable is the strength of the layer-interlayer H-bonding. A covalent $\mathrm{M}^{\mathrm{II}}-\mathrm{OH}$ bond, reflected by a short bond length, as in the $\mathrm{Ni}-\mathrm{Ga} \mathrm{LDH}$, is less conducive to hydrogen bonding, whereas an ionic $\mathrm{M}^{\mathrm{II}}-\mathrm{OH}$ bond polarizes the $\mathrm{O}-\mathrm{H}$ bond increasing the strength of H-bonding.

The SEM micrographs (figure 7, supporting information SI 3) show that the crystallites in all cases have a hexagonal platelet morphology. The in-plane growth leads to a large negative change in free energy, an account of strong iono-covalent bonding, whereas the out-of-plane growth is mediated by weaker forces, in part due to H-bonding. Homogeneous precipitation leads to well defined, dispersed crystallites, with sharp edges and clear facetting along [001]. The crystallite size is also uniform.

The question arises as to why the products of HPFS reactions are highly ordered. Urea is a weak Bronsted base $\left(\mathrm{pK}_{\mathrm{b}}=13.8\right)$ and is highly soluble in water. The rate

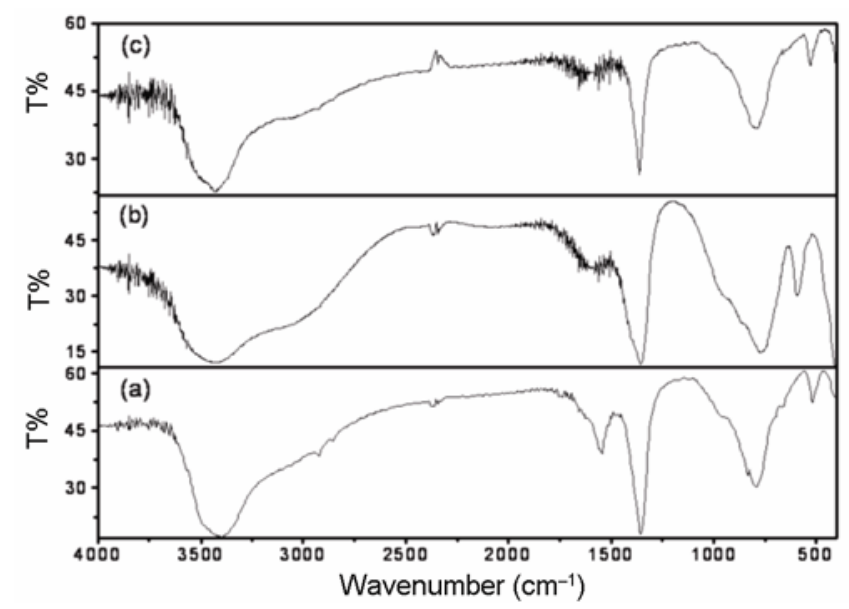

Figure 6. Infrared spectra of (a) $\mathrm{Co}-\mathrm{Ga}-\mathrm{CO}_{3}$, (b) $\mathrm{Mg}-\mathrm{Ga}-$ $\mathrm{CO}_{3}$ and (c) $\mathrm{Ni}-\mathrm{Ga}-\mathrm{CO}_{3} \mathrm{LDHs}$. of hydrolysis of urea can be easily controlled by altering the temperature of the reaction. The mechanism of urea hydrolysis involves the formation of the ammonium cyanate which is the slow and rate determining step. The ammonium cyanate formed undergoes fast hydrolysis to give ammonium carbonate (Shaw and Bordeaux 1955).

$$
\begin{aligned}
& \mathrm{CO}\left(\mathrm{NH}_{2}\right)_{2} \leftrightarrow \mathrm{NH}_{4} \mathrm{CNO}, \\
& \mathrm{NH}_{4} \mathrm{CNO}+2 \mathrm{H}_{2} \mathrm{O} \rightarrow\left(\mathrm{NH}_{4}\right)_{2} \mathrm{CO}_{3} .
\end{aligned}
$$

The hydrolysis of urea results in the increase in the $\mathrm{pH}$ of the reaction medium which is adequate to precipitate a large number of metal hydroxides.

This method has been extensively used for the preparation of LDHs (Costantino et al 1998; Adachi-Pagano et al 2003). Urea hydrolysis leads to a low degree of supersaturation and facilitates slow and steady crystal growth after nucleation. The LDHs prepared by urea hydrolysis
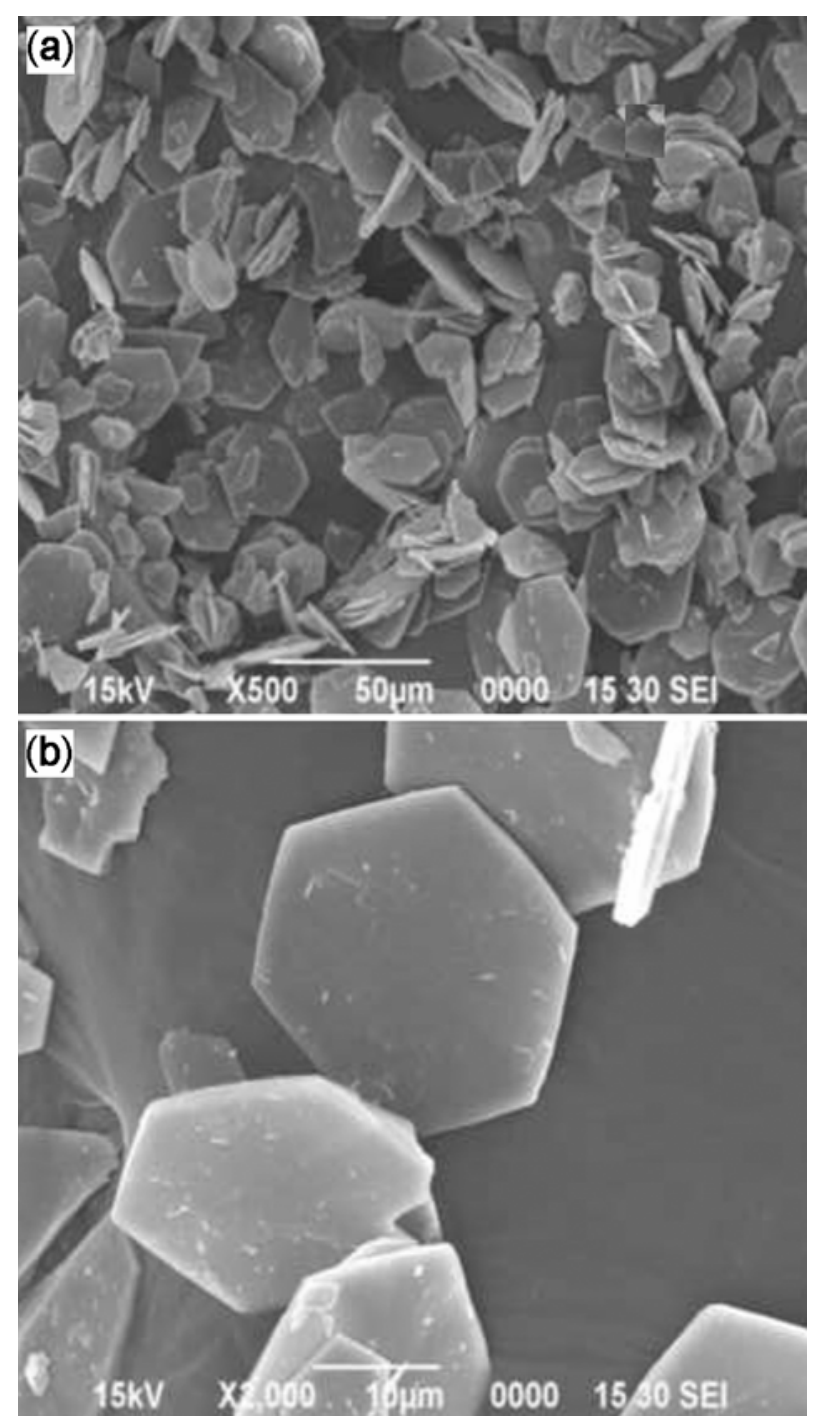

Figure 7. SEM images of $\mathrm{Mg}-\mathrm{Ga}-\mathrm{CO}_{3} \mathrm{LDH}$ at (a) low magnification and (b) high magnification. 
are, therefore, well crystallized and monodispersed when compared to those prepared by the conventional co-precipitation method.

\section{Conclusions}

In conclusion, homogeneous precipitation by urea hydrolysis yields highly ordered polycrystalline samples of layered double hydroxides. Structure refinement shows that the coulombic forces are independent of the divalent ions whereas the $\mathrm{H}$-bonding varies with the divalent ion.

\section{Acknowledgements}

The authors thank the Department of Science and Technology (DST), Government of India, for financial support. One of the authors (PVK) is a recipient of the Ramanna Fellowship of DST.

\section{References}

Adachi-Pagano M, Forano C and Besse J P 2003 J. Mater. Chem. 131988

Allmann R, Jepsen H P and Jhb N 1969 Miner. Mh. 12544

Aramendia M A, Borau V, Jimenez C, Marinas J M, Romero F J and Ruiz J S 1997 J. Solid State Chem. 13178

Aramendia M A, Borau V, Jimenez C, Marinas J M, Romero F J and Urbano F J 1999 J. Mater. Chem. 92291

Bellotto M, Rebours B, Clause O, Lynch J, Bazin D D and Elkaïm E 1996 J. Phys. Chem. B100 8527
Bookin A S and Drits V A 1993 Clays Clay Miner. 41551

Cavani F, Trifiro F and Vaccari A 1991 Catal. Today 11173

Costantino U, Marmottini F, Nocchetti M and Vivani R 1998 Eur. J. Inorg. Chem. 1439

Defontaine G, Michot L J, Bihannic I, Ghanbaja J and Briois V 2000 Langmuir 209834

Drits V S and Bookin A S 2001 in Layered double hydroxides: past and future (ed.) V Rives (New York: Nova Science) pp. 39-92

Fetter G, Ramos E, Olguin M T, Bosch P, Lopez T and Bulbulian 1997 J. Radioanal Nucl. Chem. 63221

Gago S, Costa T, Seixas del melco J, Goncalves I S and Pillinger M 2008 J. Mater. Chem. 18894

Grardin C, Kostadinova D, Sanson N, Coq B and Tichit D 2005 Chem. Mater. 176473

Grosso R P, Suib S L,Weber R S and Schubert P F 1992 Chem. Mater. 4922

Gursky J A, Blough S D, Luna C, Gomez C, Luevano A N and Gardner E A 2006 J. Am. Chem. Soc. 1288376

Hines D R, Seidler G T, Treacy M M J and Solin S A 1997 Solid State Commun. 101835

Khan A I and O'Hare D 2002 J. Mater. Chem. 123191

Radha A V, Shivakumara C and Kamath P V 2007 Acta Crystallogr. B63 243

Reichle W T 1986 Solid State Ionics 22135

Rodriguez-Carvajal J 2005 FULLPROF2K Code ver. 3.3 (http://2221lb.cea.fr/fullweb/powder.htm)

Shannon R D 1976 Acta Crystallogr. A32 751

Shaw W H R and Bordeaux J J 1955 J. Am. Chem. Soc. 774729

Taylor H F W 1973 Mineral. Mag. 39377

Thomas G S, Rajamathi M and Kamath P V 2004 Clays Clay Miner. 52693

Zhao Y, Li F, Zhang R, Evans D G and Duan X 2002 Chem. Mater. 144286 